\title{
The Gradualism of Cultural Resurgence of Afro-Arabic in the Shadow of Civilization
}

\author{
Fatai Owolabi Jamiu \\ Tai Solarin University of Education, Ijagun \\ Ijebu-Ode; Ogun State, Nigeria \\ fatja_min2@yahoo.com \\ DOI: https://doi.org/10.32890/jis2017.13.9
}

Abstract

Intellectual vitality of the Arabic culture came into stagnation through the close of the $18^{\text {th }}$ century. However, the beginning of the $19^{\text {th }}$ century potrayed the rebirth of the Arabic culture seen first in Lebanon, Syria and Egypt, from where it spread gradually in varying degrees to other parts of the Arab world. This cultural resurgence with its full import of the Arab Muslim society especially in Africa has prompted the rise in Arab national consciousness (nationalism) as well as religious (Islamic) reawakening, which have a wonderful over effect on the contemporary World Order. The methodology adopted in this paper was document review. This paper tried to investigate the gradual process of the Arabic cultural resurgence, which has found expression in the shifting paradigm of Arabic literary works of some literati and religious revivalism in Africa. In fact, it is noticed that Arabism has been an integral part of Islam; the activities of the nationalist movement and that of Islamic reformers have political and cultural consequences in the modern world.

Keywords: Africa, Arab world, Islam, culture.

\section{Concept of Inhitat (Decline) and Nahdah (Renaissance) in Arabic Literary Categorization}

Any attempt to discuss the veracity of the expression 'asr al-Inhitat, i.e. the period of (intellectual) stagnation, especially in the case of Arabic literary development is still in progress. This is due to a lot of expressions on the issue. Many scholars are of the opinion that there was a particular period in which the rapid rise of Arabic to major significance, shown impressively in its extensive literature, came to a complete standstill beginning from the thirteenth century to the end of the eighteenth century while some others disagreed. It was argued that the bulk of intellectual but literary production during the said period was enough to absolve it from such an obnoxious description.

It has been observed that Arabic language and literature were available to give impetus to the religious need but the establishment of dogmatism by al-'Ash'ari and al-Ghazali propelled 
the expansion of Arabic and literary production in the language, which according to Chejne, to gradually lose momentum and head for a slow but sure decline (Chejne, 1969). In fact, its intelligentsia was infected through the bewilderment and frustrations of the political period which, in turn, failed to match the excellence of their predecessors in terms of literary production. This Arab cultural backwardness started from the fall of Baghdad in 1259 and came to an end with Napoleon Bonaparte's invasion of Egypt in 1798 which is regarded as one of the factors that led to the decline in the quality of Arabic literature.

It is, however, believed that the main factors of this decline was attached to: the disintegration of the strong Muslim empire and the rise of many provincial governments which led to the replacement of Classical Arabic by Persian and Turkish; the interactions with nonArab territories which led to the ascendancy of both Arabicized and colloquial Arabic; the fall of Baghdad which gave rise to the imposition of non-Arab rulers and made them cut off gradually from their original cultures, etc. These and some other factors led to the preponderance of imitation and compilation during the period rather than production of original literary works. It pointed to excessive emphasis on literary artificiality which made the language weak and facile (Ogunbiyi, 1982).

From another angle, the period of Inhitat (decline), as observed by some scholars of Arabic literary history, (Olalere, 1993 in Kritzeck, 1964) indicated that there might not be any reasonable justification for the sweeping statement that the then literati did not produce any literary work worthy of consideration. This, according to the advocates of this view, presupposes that it would be erroneous to conclude that the development of Arabic and its culture came to a complete stagnation in the period. The reason for this, to some extent, is that certain literary and intellectual contributions were made in the field of compilations and encyclopedias, without which our knowledge of Arabic lore would be very limited.

Furthermore, some of the extant works of the period are still very invaluable references. The significant contributions of literary works of scholars such as al-Nuwayri (d.1332), al-Safadi (d.1363) al-Qalqashandi (d.1418) and al-Baghdadi (d. 1674) cannot be overemphasized in the areas of Arabic literature and history, Panegyric poems such as Hamziyyah and alBurdah of al-Busiri (d.1296) and Lamiyat of Ibn Wardi (d.1349). are some of the best examples of literary output of the period in question.

The popular view, however, has it that the particular period had experienced a kind of literary stagnation compared to the previous periods. Nevertheless, there was a considerable number of literary production, which could still be referred to as serving the interregnum role between the period of the fall of Baghdad and the invasion of Egypt by Napoleon in 1798. This period was believed by the Arabic literary historians to mark the beginning of the modern Arabic literary culture.

The invasion of Egypt at this period was an event that initiated and hastened the process of social, political and literary awakening of the literati in particular (Hourani, 1962). The 
consequence of the subsequent interaction between the West and the East was the rebirth and renaissance as well as cultural consciousness, particularly on the part of the latter, which gave rise to the shifting paradigm in the literary production of the scholars and it's over effect on the New World Order as we shall see later in this work.

\section{AL-Nahdah (rebirth) in the Modern Arabic Literary Culture}

The close interaction between literature and socio-political issues in modern Arabic literacy makes it difficult to isolate one from the other. In fact, literature depicts the life of a particular society in a given period of time whereas the importance of the socio-cultural dimension of the society is particularly relevant in dealing with human experience and derives its significance from probing it. As the military objective of the permanent French occupation of Egypt failed, the political and cultural awareness, which it left on the Egyptians contributed immensely to the development which took place in Egypt with its attendant results in the rest of the Arab world in the $19^{\text {th }}$ century and beyond.

It is on record that while Egypt had its contact with the Napoleon Bonaparte in the close of the 18th century; Lebanon had entered into contact with the West as early as the seventeenth century. This relationship remained uninterrupted owing to the interest of the papacy and other religious groups, which later made the Fertile Crescent, mainly Syria-Lebanon, the leader of intellectual revival ${ }^{1}$. The renewed contact with the West kindled in the average Arab the extent of their backwardness in contrast with the advancement taking place in Europe. By the $18^{\text {th }}$ century, the clerics had laid the foundation for the revival of the Arabic language in spite of its originally religious orientation. This revival contributed a great deal to the creation of modern Arabic literature.

Furthermore, Muhammad 'Ali of Egypt, for instance, endeavored to embark on a military enterprise rather than a cultural mission in Europe where he sent a number of Egyptians to study. Consequently, many of them could not immune themselves from the environment as other areas of knowledge such as medicine, engineering, language, literature, etc. were beneficial and developed indirectly. Hence, the intellectual-cum-technological upheavals which Europe had passed through - the Renaissance, the reformation and the Industrial revolution-were all brought to the Arab world. In fact, many books in the various fields of knowledge were translated into Arabic; the educational system was restructured. Printing presses, above all, were established not only to produce the books translated from other languages but also to produce numerous copies of rare books and manuscripts by classical Arab writers ${ }^{7}$ at cheap prices.

It is interesting to note that the adoption of the Western literary modes came much later than western technology or even western thought. This was as a result of the earlier inherent difficulty in adapting to the alien cultural products as literature with its infinitely subtle and complex elements, which require not only a thorough and intimate knowledge of a foreign 
language, but also a complete readjustment or reeducation of sensibility (Badawi, 1970). With the availability of the printing press in particular, a substantial level of development was noticed in Egypt, particularly in the area of disseminating knowledge of current events and historical topics as well as forums where important social issues were discussed by the intelligentsia. This singular opportunity made many Syrians and Lebanese flock into Egypt in search of freedom of speech and they founded several publications.

Westernization in Turkey had a profound impact upon Indian Muslims. They too, thought of changing their lifestyles and sought to establish cultural links with the West as they adopted European cultural values. In fact, most of these values are considered diametrically opposed to Islam. Thus, reformers such as Abul A 'la Mawdudi in the Indian sub-continent sought to break the hold which Western culture and ideas had over the minds of Muslim intellectuals by a critical analysis of the Western system showing its weaknesses and shortcomings. In this case, there has been sharp distinction between the Arabo-Islamic civilization and that of the West, as Islam has its own code of life, culture, philosophy, politico-economy and ideology etc. which are not the same with the West. The two are different conflicting systems whose co-existence has rather been observed as a clash of (culture) civilizations by some socio-political analysts.

\section{Arabo-Islamic Cultural Awareness And Neo-Classicism in Afro-Arab World}

There was the quest for cultural identity, heart searching, and at times agonizing self analysis to which the Arabs were driven through in their interactions with western culture. All these kept reflecting in the works of the literati. Since Islam has been an integral part of Arabism, religious consciousness arose in them, which gave birth to religious revivalism and reformation. The stirring of nationalism, in the form of rediscovery of the classical Arab literary heritage coincided with the wave of religious revivalism in Egypt led by the intelligentsia who were concerned with reviving the socio-political and more importantly cultural structure of the country. They had the task of establishing the basic principles of Egyptian enlightenment, the rediscovery of the true spirit of Arab cultures and its historical links with other world cultures, and the analysis of its relation to new aspirations and demands. These thinkers, beginning from Muhammad Ali formed the crop of precursors of the Egyptian Arab culture whose ideology later influenced contemporary Arab literati such as Taha Husayn, 'Abbas Mahmud al-'Aqqad, Ibrahim 'Abd al-Qadir al-Mazini, Abd al-Rahman al-Rafi' $i$ and a host of others. This gave rise to neo-classicism in the Arabic literature of the nineteen century.

In fact, their ideology partly lay in the dialogue they encouraged between Arab culture and that of the rest of the world. Their goal was the invigoration of Arab culture, which they hoped would lead to the establishment of the Arab identity not only in Egypt but also throughout the Arab nations. Their loyalty to Arab traditions more discernible in their literary writings, which were aimed at enhancing and renewing tradition while looking into the future. 
In a comparative study of the Islamic and Western political and philosophical thinking, al'Aqqad, for instance, engaged in Islamic thought through the introduction of challenging Western ideas. However, he never lost faith in the capacity of the Arab culture to renew itself, develop and modernize in the face of such challenges; it was to past and contemporary Arab literature, that he always returned bringing with him an established interest in Western culture. Appealing to foster nationalism, these nationalist movement icons worked towards restoring to the people a sense of pride in themselves, though combining their traditions and that of Western thought.

With the attempt towards rethinking classical Arabic literary culture, Arabic literature witnessed a dramatic change and continuity as poetry, for instance, metamorphosed from one school to another, all in the bid to transcend the considered period of stagnation in the literary culture. Nevertheless, neo-classicism dominated poetic creativity from the last decade of the nineteenth century through the $1920 \mathrm{~s}$, and has never realy died out ${ }^{2}$. The literary ideology did not however, go unchallenged especially by the group of poets and critics both in Egypt and in North America, who began their direct attacks on them. These émigré poets in America were led by Gibran Khalil Gibran. Besides, the Egyptian school popularly known as Diwan also launched an attack on the neo-classicists whose aim was to revolutionize the stable emphasizing the subjective element of experience ${ }^{3}$.

Precisely, the Arab Romantic Movement from America to Egypt spread to other Arab countries wherever there were acute feelings of deprivation, or a discrepancy between aspiration and reality, especially on the personal and social plane ${ }^{4}$. In 1920, ar-Rabitat al-Qalamiyyah (lit. Pen League) a literary society which had a deep impact on modern Arabic literature, was founded in New York. Its members were Gibran, who was elected president, Nuaymah Abel Messih Haddad, Illia Atta Allah, William Katzeflis, Nassib Arida and Rashid Ayub. The members of Al-Rabitah, effected a revolution in Arabic literature comparable to that of the English and French Romantics a century later(Ashour, 1978). Annually, al-Saih, an Arabic newspaper in New York issued a literary review to which they all contributed. In fact, in 1921, al-Rabitah published an anthology which contained poems, stories and essays by its members. It is interesting to mention here that Nuaimah's introduction was the manifesto of this late Romantic Movement ${ }^{5}$.

\section{Influence of the Émigrés}

While poets such as Abdul Rahman Shukri and Ma'ruf al-Rusafi were working in the Arab homeland in this century's ealier decades, others such as Gibran Khalil Gibran, Mika'il Nuaimah and Nasib Arida were writing in the new world. These and other émigrés, pursuing lives less confined by tradition and less difficult politically, were able to exert a significant influence on the directions writing took in their native lands but later, Gibran was had considerable influence on the West itself.

The earlier 'moderns' were important, not only for reflecting what was happening in the Arab World at large, but also for the effects their thoughts had in moulding the course of 
many kinds of future events. Their successors, for instance, inherited a deeper understanding of the West and its literary and philosophical movements. The main efforts of these earlier poets were directed, in large part, towards an interpretation of the forces of change in the re-awakening Arab World of their period - efforts which led to recognition of a need for a restatement of al-Rabitat Qalamiyyah in New York in 1920. The émigré stated:

Not everything parading as literature is literature; nor is rimester a poet. The literature we esteem as worth is that only which draws its nourishment from life's soil, light and air.... This new movement, aimed at transporting our literature from stagnation to life, from imitation to creation is worthy of all encouragement; on the other hand, if our language and literature are kept within the narrow bounds of imitation to creation they are worthy of all encouragement; on the other hand, if our language and literature are kept within the narrow bounds of imitating the ancients in form and substance, this tendency will lead to decay and disintegration (Joseph, 1984).

Continuing the late nineteen century preoccupations, poets such as Gibran were clearly concerned with primary philosophical problems, and aimed at coming to an understanding of their changing world. They addressed themselves to speculative matters such as the nature of the universe and God - few were interested in ambling camels and ruins, except for occasional illustrative purposes. Their main interest was the problem of knowledge and the understanding of nature - as it had been for thinkers during the Renaissance in Europe. The problem, however, in the Arab world was more acute because that world had been hurled the into twentieth century from a recent medieval past and was still maintaining traditions considered ossified by 'modernity-oriented' Arabs. For their world, the onset of the twentieth century brought multidimensional shocks that the region is still dealing with today. In response, the poets have directed efforts to articulate comprehension, make interpretations, and indicate new directions for their people.

\section{The Role of the Contemporary Poet}

The principal role of the Arab poet has always been that of a spokesman for his people, and though still holding true, it has been expanded. Modern poets do more than merely reflect the joys and sorrows of life; they are also its interpreters. Some observers such as the late Najm Bezirgan stress the poets' role as guides in mapping out courses of social action through their contributions to the stream of ideas. They may, for example, urge fresh interpretations of the messages in the Holy Qur'an as do Nizar al-Quabbani in "Bread, Hashish and Moonlight," or Badr

al-Sayyab, in "The Blind Prostitute." Such work reflects people seeking directions through confusing alternatives.

Within the framework of social and economic revolution, poetry, inevitably, will reflect a diversity of approaches to innovation; although of course, responses and emphasis differ 
according to which particular aspects of life were engaging individual attention. Thus, for example, the work of al-Sayyab has primarily mirrored the political scene while he continued to work on the means of effective expression - one of his major concerns says:

behold the defeat of heroism

Death indeed has shattered every hope within you,

And you have advanced with the wandering look

And an empty fist 6

Another, Abd al-Wahhab Al-Bayati, is a socialist realist with similar kinds of concerns, while yet others such as Fadwa Tuqan and Harun Al-Rashid have focused on the political and human tragedy of Palestine.Contemporary poets have exhibited considerable courage in exercising their innovations because poetry, like the classical language, is a part of life very dear to the Arab psyche. Luwis Awad's "Plutoland," for instance, was banned in Egypt because he stated, among other controversial things, that the old forms of poetry "were dead." Tampering with the themes and forms of poetry are regarded with suspicion, at the least, and as traitorous at the worst. Certain poets such as Adunis, among the most influential, have incorporated political statements into their verse and earned exile. Their utterances have been construed as dangerous or unrepresentative of the people's sentiments - although the people may, in fact, be the particular elite ruling at the time. Mutran says:

..... A dwarf whom they raised on high,

They crawled before him and he grew in arrogance, They glorified him and extended his shadow........ .........Every nation creates its own Nero ${ }^{7}$.

Since this century's mid decades, poets have continued to articulate the agonies suffered by their societies in their struggles to grow and reform themselves. Progress has been retarded by military defeat and preparation for further war in environments of economic underdevelopment. Thus, the poets have addressed themselves to reasons and causes for their nations' continued suffering, as for example, Mutran in "Nero," by drawing attention to archaic or tyrannical systems of government and their empty rhetoric, or Al-Qabbani in his, "What value have the people whose tongue is tied?" In his poem, "Bread, Hashish, and Moonlight," he remarks:

Where we slowly chew on our unending songs, a form of consumption destroying the East our East chewing on its history ......

Its lethargic dreams

Its empty legends

Contemporary poets have articulated so many of the concerns of their people in their world; as a group they have been, in general, fundamentally disenchanted with obsolete and 
ineffectual modes of thought and behaviour they see in their homelands. Thus, Al-Sayyab remarks that these mind-sets are:

Clothing them in ancient banners

That exudes the swell of defeat.

("Before the Gate of God")

Frustration has been increased by the discrepancy between ideals and reality, and the resulting alienation furthered by the tension generated by the very rapid social change due to economic growth and modernization. Thus, Nazik Al-Mala'ika cries "Who am I?", and Al-Haydari bemoans as follows:

\footnotetext{
.....No, I shall not return

For whom should I return?

My village has become a city.

.....here there is nothing I know

And nothing that knows me.
}

(“A False Step")

It is interesting to note that in their efforts to find even more meaningful imagery and modes of expression, as well as some relief from pain and sadness, the poets have adopted from sources hitherto alien to the main traditions of Arabic poetry. Christian notions of crucifixion, death, and resurrection have, for instance, been used extensively by Al-Sayyab in work addressed to a primarily Muslim world. He says:

I long to sink to the depths of my blood

To bear my load with other men

To resurrect life. Then is my death a victory.

(“The River and Death")

On the other hand, the activities of the religious reformers left indelible mark in the minds of the Arab people. In fact, Jamal al-Din al-Afghani (1839-1897) was one of the outstanding religious reformers. He was one of the precursors of the subsequent Islamic reformers of the twentieth century. His view of emancipating the minds and souls of average Muslims from the shackles of superstition, and particularly establishing true precepts of Islam had a significant impact on the whole Middle East and greatly influenced his Egyptian disciple, Muhammad 'Abduh (1849-1905) and the Syrian, Rashid Rida (1865-1935). These two great religious reformers contributed immensely to the process of Islamic revivalism in the beginning of the $20^{\text {th }}$ century. Another contemporary Egyptian Islamic reformer was Hassan al-Banna (d.1949) who established the Ikhwan al-Muslimum (The Muslim Brotherhood) in Egypt in 1928 and advocated for revivification of Islam and the establishment of political and social institutions in line with the Islamic precepts (Aly, 1977). 
It is important to note here that Hassan al-Banna was intellectually a combination of Muhammad 'Abduh reformism, Rashid Rida conservatism, and al-Afghani's political activism. He conceived his mission as a more comprehensive vision of Islam. One of his followers summarized his view of al-Afghani as "merely a cry of warning against problem," of Abduh as "merely a teacher and philosopher," and of Rashid Rida as "merely a historian and a recorder" while The Muslim Brotherhood, on the contrary, means "jihad, struggle and work - it is not merely a philosophical message"

As an instrument of religion, the intimate relationship between Arabic and Islam is reflected in the attitudes and beliefs of average Arab Muslims over the centuries. To the religious significance of Arabic may be added its important role in the Arab - Muslim culture. The intelligentsia, in the nineteenth century, essentially agreed that intellectual revival and national consciousness have Arabic and historical traditions as their indispensable foundations ${ }^{9}$.

With this Arabo-Islamic cultural awareness in Egypt and some other Arab worlds in the said period, there were conflicting ideas concerning the approach to the modern trends and waves of changes in the socio-cultural settings in the regions. These conflicting views cut across the Islamic reformers and the nationalist movement whose belief was based on the traditions of Islam and the progressive dedication to the establishment of an independent and sovereign state. Though on the surface, the two dominant movements appeared to have different goals, essentially they had one significant drive for the establishment of an Arabnation state.

It was widely believed by the reformers that both Islam and Arabic culture were really under attack by Western beliefs and culture. Hence, there was a need for salvation of their cultural heritage. This is why the objectives of the groups had much in common, as the leaders of both the reformers and the nationalist movement had the reason for them to work together and repel the common enemy.

\section{Arabo-Islamic Resurgence in the Modern World}

Arabo-Islamic resurgence in the modern world was a wide-spread traditional, cultural and political phenomenon in modern times. It was like a revolution, which exerted both spiritual and moral forces. The scientific combination of the two has made an indelible mark in the history of modern times. This development generated an influence which was felt all over the place as it spread across the Muslim worlds. It should be mentioned that the rise of this development has been more of religious ideology rather than cultural and or civilization as some writers might want us to understand. The reformers or the revivalist movement, whose ideology was more of Islam in orientation, used this in their awareness campaign, which culminated in the degree of successes it achieved. They were also often critical of specific aspects of the secular colonial as well as the post-colonial state. 
The effects of the revivalism and reforms were very apparent in most of the contemporary Muslim worlds that saw the West and its ideology as diametrically opposed to that of Islam. Hence, attempts have been made all along that the leadership of the West must be substituted by that of Islam. It resulted from the diagnoses consistently voiced by veteran $19^{\text {th }}$ century Muslim reformers such as Muhammad 'Ali, Sayid Jamal al-Din al-Afghani, Shaykh Muhammad Abduh, Sir Sayyid Ahmad Khan and their later counterparts like Allama Sir Muhammad Iqbal, Shaykh Muhammad Qutb, Malik Binnabi, Maulana Abul A 'la Maududi and others in the aftermath of the impact of European colonialism of Islamic lands.

The common denominator of their diagnoses, however, was that a revival of Islamic ideology, culture, and civilization based on Islamic ideology was the only alternative to the Western but un-Islamic cultural orientations. This could be achieved through the reconstruction of the Islamic ideology based on concepts enshrined in the Holy Qur' an and Sunnah (tradition) of the Prophet, and a re-organization of Muslim life reflecting that ideology.

This revivalism, which took the populist pattern as could be seen from the activities of the Ikhwan al-Muslimun, the Muslim Brotherhood of Hassan al-Banna, Jama'at al-Islamiyyah, in Indo-Pakistan of al-Maududi, and the $20^{\text {th }}$ century Islamic Revolution in Iran of Imam Ayatullah Khomeini. If had dominated the hearts and won the admiration and sympathy of the third world where Muslims were preponderates. They drew their support primarily from the bazaaris-people working as craftsmen, peddlers, shopkeepers and workers in the old-fashioned economy; maktabis-minor clerks, school teachers, students, displaced or unemployed intellectuals; migrants from villages to cities, and students, usually in the technical faculties such as pharmacy or engineering, who had a good education and high hopes but did not find adequate employment and remuneration (Ibrahim, 1980). This development, no doubt, has generated projections from political thinkers of the possibility of 'clash of cultures?' or better still ideologies. Today, no one is left in doubt concerning the tremendous impact of this revivalism and religious reformation in the shadow of to borrow from George W. Bush Jr. the 'New World Order'

Muslim movements of 'reform', or tajdid (renewal, rejuvenation), are the attempts to achieve social and religious changes. 'Reform' is, thus seen as a conscious and intentional effort to achieve social, religious, cultural, political or economic changes with respect to a specific society or specific aspects of social life (Loimeier, 2003). The Muslim revivalists have thus used religion as a platform to express political disinterestedness and to delegitimize the the political authority of the West, often described as 'unjust'. Although, according to Loimeier, these features of reform may not be shared by all movements of reform at all times, they form the core of reformist initiatives since, probably, the $19^{\text {th }}$ century, and seem to have, if reduced to their very abstract structure, an almost 'Protestant' reformist quality, even when we take into account that a number of important differences still exist, such as, for instance, the attributed nature of the Bible and the Qur' $a n^{10}$. 


\section{Current Developments}

The Arab Muslim World that particularly appeared in the first instance as a reform in Egypt, and even Indo-Pakistan later, became a wide event. The pulse of the Islamic civilization, which had started to beat weak long before and hence, the onslaught in the $18^{\text {th }}$ and $19^{\text {th }}$ centuries on the Europeans who easily defeated, colonized and subjugated Muslims in all places. Notwithstanding, over two centuries of contact with the European civilization and the vigorous impact of its technological culture, did not by itself, normalize the pulse beat of the Islamic civilization. It should be stated here that in spite of the Muslims being humiliated, jolted and weakened by colonialism, they, however, did not abandon hope of making a recovery.

It is disheartening to note that the reforms set ablaze among Muslims the same old zeal and quest for comprehensive excellence in Islamic culture and ideology as distinguished by them during the glorious phase of Islamic civilization from the $9^{\text {th }}$ through to the $16^{\text {th }}$ centuries, a phase which has been known as the creative and adaptive period of Islamic civilization. All the attempts collectively corroborated the urge to reformulate the envisioned Islamic ideology. Hence, there were series of reforms in the areas of politics, economy, social and culture. There was an attempt to put an end to the cultural/ideological warfare by the West in most of the Muslim lands. The Muslim thinkers continued to educate the masses that Islamic alternatives were the only answers to the repressive system of the colonial masters. Muslims, therefore, must sincerely and faithfully strive to establish a constitutional movement that would enthrone Islam as a system of government where there is an opportunity for that.

The Muslim world all over has been trying to strategize and thus organized a series of attempts in that direction. For instance, the Islamization of knowledge project came up as a result of this development. The efforts of the late Islamic thinker, Isma 'il Raji al-Faruqi and others must be credited for this initiative, which has today germinated into the formation of the Association of Muslim Social Scientists, the establishment of the International Institute of Thought, the Organization of Islamic Conference, the Qaedah network, the Talliban, al-Hammas, the Muslim Brothers and the Jama'at in Egypt, al-Nahda in Tunisia, FIS in Algeria, the Jama'at Islami in Pakistan and elsewhere in South and South east Asia, and Shi'i movements in Lebanon such as Amal and Hizbullah as well as other organizations whose ideology is that of Islam in varying forms.

While some of these attempts were approached via organizing seminars, symposia, conferences, etc. other Muslim activists like Abul A'la Maududi took the path of writing whose approach of $d a^{\prime}$ wah (call into the way of Islam) was unique to that of Imam Hassan al-Banna in Egypt. The adage which says that the pen is mightier than the sword becomes more practically true than ever in the particular case of some reformers such as Muhammad Abduh, Rashid Rida and Hassan al-Banna. During their days in Egypt, for instance, Muslim thinkers like Muhammad 'Abduh and Rashid Rida established a magazine known as alUrwat al-Wuthqah ${ }^{11}$, which served as a means of reaching the populace in educating them of the efficiency of Islamic ideology. 
In fact, their writings motivated a great deal of their disciples to political activism. Isma'il Raji al-Faruqi employed the use of the pen in his propagation career before finally being assassinated sometime in 1986. Abul A'la Maududi's writings ${ }^{12}$ such as al-Ijtihad fi alIslam, a treatise on the Islamic law of war and peace, The Islamic Constitution, Towards Understanding Islam, etc. in the India sub-region with his characteristic subtle style and manner of approach have played significant roles among the elites. In the same vein, the literary works of Allama Muhammad Iqbal have also equipped many elites with basic principles of Islam. These Islamic thinkers symbolized respectively the intellectualists' and the activists' trends within the Muslim community in modern times.

It is interesting to mention here that the activities of the International Institute of Islamic Thought particularly from the last decade of the $20^{\text {th }}$ century to date have recorded tremendous success in re-orientating the minds of the contemporary Muslims. A series of symposia, conferences as well as publications of well researched articles with particular Islamic bias over the years have told it all. In the 1970s, the Saudi Arabia Government sponsored three pioneering World level conferences: the 1975 Islamic Solidarity Technology Conference held at Riyadh, the 1976 First World Conference on Islamic Economics held at Makkah and the 1977 First World Conference on Muslim Education held also at Makkah.

On the list of impacts of the contemporary reforms in the Arab Muslim world is the establishment of research centers in various languages not only in the Muslim world but also in western countries at prominent institutions. The Oxford Center for Islamic Studies, being a center for the study of the Islamic world, is an associated institution of Oxford University which has links with universities and research centers throughout the Muslim world. Its primary purpose is to promote a more informed understanding of Islam and the Islamic world by means of research and advanced study ${ }^{13}$. The center encourages multidisciplinary studies and its academic focus is not restricted to any one discipline or world religions. It offers research fellowships to support studies in any area of the Arts, Humanities and Social Sciences which have relevance to the study of Islam or the Muslim world ${ }^{14}$. Prominent among its publications are periodicals such as the Muslim Education Quarterly, the American Journal of Islamic Social Sciences, the Journal of Islamic Science and Periodica Islamica.

\section{Conclusion}

From the foregoing, efforts have been made to explain in brief the gradual process of the beginning of the Arabic culture from the age of intellectual-cum-literary stagnation through the Neo-Classical period, when there was a kind of intellectual consciousness to the later period when the idea of rebirth came up. This cultural resurgence, which virtually started in Egypt (Africa) and Lebanon as well as Syria and later spread to other parts of the Arab Muslim world in varying degrees brought along Islamic revivalism and reform of Islamic ideology as part of Arabism. 
The activities of the Arabo-Islamic scholars started from Egypt in the farther part of Africa, and places like Syria and Lebanon later came to influence the trend of political and cultural patternt controlled by the West. The fact that this religio-cultural consciousness on the part of the Arab-Muslim world as well as the third world has seriously generated a sense of casting another look at the dimension of the New World Order. Thus, scholars who have seriously applied themselves to the study and evaluation of world history have sounded clear alarms for the impending and inevitable clash of civilizations or cultures on the chess board of world politics.

It is generally believed that the appearance of a succession of reformers who left indelible marks and impression on the hearts and minds of the Arab people has demonstrated the most significant development of the success of Arab revivalism. Muhammad Ibn Abd al-Wahhab (1703-1791), one of the earliest reformers, conceived the idea from his wide travels to many places where Islam was being practised with syncretism which prompted him into launching a religious movement aimed at the old puritanical Islam (Hiti, 1979). This attempt, which was greeted with huge success at last, gave impetus to succeeding reformers like Jamal alDin al-Afghani and his disciples in Egypt.

The influence of the émigré poets whose preoccupations were clearly concerned with primary philosophical problems and aimed at understanding their changing world has been explained. Contemporary poets played significant roles such as mapping out courses of social action through their contributions to the stream of ideas, urged for fresh interpretations of the messages in the Holy Qur' an and focused on the political and human tragedy.

\section{References}

Aly, S. A. (1977). Hassan al-Banna. Cairo: Dar-al-fikr.

Ashour, R. (1978). Gibran and Blake: A comparative study. Cairo: The Associated Institution for the Study and Presentation of Arab Cultural Values.

Badawi,M.M. (1970). An anthology of modern Arabic verse. London: Oxford University Press.

Badawi, M.M. (1992). Modern Arabic literature. London: Cambridge University Press.

Chejne, A.G. (1989). The Arabic language: Its role in history. Minneapolis: University of Minnesota Press.

Chejne, A.G. (1969). The Arabic language: Its role in history, Minneapolis: University of Minnesota Press.

Ibrahim, S. E. (1980). Anatomy of Egypt's militant Islamic group. International Journal of Middle East Studies, 12 (4), 423-53.

Kritzeck, J. (1964). Anthology of Islamic literature. New York: Holt Rinchart.

Hitti, P. K. (1979). History of the Arabs. London: Macmillan Press.

Hourani, A. (1962). Arabic thought in the liberal age 1798-1939. London: Oxford University Press. 
Jayyusi, S. K., (1992). Modernist poetry in Arabic. In Badawi, M. M. (Eds.), Modern Arabic literature. Cambridge: Cambridge University Press.

Joseph, L. B. (1984). Modernization of the Arab world. Journal of the Islamic cultural centre. Islamic Quarterly, 33 (7).

Ogunbiyi, I. A. (1982). The poet Mahmud Sami Al-Barudi's contribution to modern Arabic poetry. Journal of the Department of Arabic and Islamic Studies, 3 (1), 1-33.

Olalere, A. (1993). I'adat al-nazar fil adab al-'arabi fil 'asril musamma bi 'asr al- inhitat. Journal of Arabic and Islamic Studies, 14 (1), 22-28.

Loimeier, R. (2003). Patterns and peculiarities of Islamic reform in Africa. Journal of Religion in Africa, 33 (3), 237-62.

Roy, O. (1994). The failure of political Islam. Cambridge: Harvard University Press.

Talfah, K., (1973). Kuntum khayr ummah ukhrijat lin-nas. Journal of Arabic Literature, 3 (4), 235-40.

Wenner, M. W.(1982). Modern Islamic reform movements: The Muslim brotherhood in contemporary Egypt. Middle-east Journal, 36(3), 336-61.

End Notes

Chejne, A.G. op.cit. 86.

Ibidem, 137.

Ibidem

Ibidem

Ibidem

Ibidem

7 Hourani, A. op.cit. 7-8.

8 Chejne, op. cit. 18.

9 Harvard University Press.

10 Ibidem. 241.

11 The Magazine was al-urwat al-wuthqa.

12 See his masterpiece on al-Ijtihad fil Islam, a treatise on the Islamic law of war and peace, the Islamic constitution, Towards understanding Islam, etc.

13 Being report of the First World Conference on Muslim Education in 1977.

14 Ibidem. 